\title{
Self-Concepts and Deindividuation in Brawl
}

\author{
Elisa Kurniadewi*, Aditya Aryo Nur Kusumo, Adang Hambali \\ \{*elisa.kurniadewi@uinsgd.ac.id\} \\ Universitas Islam Negeri Sunan Gunung Jati Bandung, Jl. AH Nasution No. 105, Bandung 40614, \\ Indonesia
}

\begin{abstract}
Behavior brawl among students seems to be a problem that is often highlighted. Students who participate in fights lose self-awareness and self-control. However, if students have good self-concepts they will still be able to maintain selfawareness and self-control. This study aims to determine the relationship between selfconcept and deindividuation in perpetrators of fights between students in high schools in Depok. Self-concepts is the perception of observing oneself, experiencing, and being valued by individuals to interact with their environment. Deindividuation that individual anonymity that changes the significance of personal identity into social identity, so that someone loses self-awareness and self-control when in a group, so that it can have an impact on individual behavior. quantitative with Pearson correlation test. The sample in this study was 80 students. The findings show that there is a negative relationship between self-concept and de-individuation in a fight in high school students in Depok.
\end{abstract}

Keywords: self-concept, deindividuation, brawl

\section{Introduction}

Brawl cases continue to increase and that the perpetrators came from the students.Amongstudents, brawl is the reality of the moral degradation or deterioration of manners[1].Just because a different purpose and school uniforms they assume people who are outside their group must be destroyed. The fight comes from the word meaning tawuran or fights mass [2]. According to Ridwan[3]mass brawl conducted by a group of students to a group of other students from different schools. Student brawls did occur between schools. Students who are not in a group tend to be quiet, do not look for trouble, and will avoid violent behavior. This will change when the student along with his group, The student turned into a brave man as if he was not afraid of anything and anyone. The group would have negative impacts on the individual learner, the brawl. The impact of those that affect individualbehavior like this in psychology known as de-individuation.

Deindividuation term was first proposed by Festinger, Pepitone and Newcomb (1952). Deindividuation is a situation where a person loses awareness of self and loss of sense of evaluative against him in a group situation that allows anonymity and diverts or draw attention away from the individual [4]. Deindividuation occurs when a person commits antisocial acts undesirable because of the interest of individuals in the group.A person may experience deindividuation if it has much in common with other group members, convinced that his 
actions will not be considered as an act of an individual, but as a class action, and was not going to be held responsible for the actions he did [5]. Based on the phenomenon that the author got from the interviews that the cause deindividuation on student brawl is the figure of the hero, a large number of groups, and ridicule or harsh words that were raised by other school students. One of the factors, namely ridicule and harsh words were thrown, causing the loss of self-control is already owned, self-evaluation and self-awareness that students are exposed to ridicule [3]. According to Brooks and Emmert (1976) people who are sensitive to criticism or cannot stand criticism will easily get angry; tend to feel disliked by others, and consider other people as enemies are characteristics of people who have a negative selfconcept[6]. Also, according to Rachmat (2012), our tendency to behave by the concept of self is referred to as behavior that might occur. If we consider ourselves stupid, then we will be lazy to learn. If we find ourselves good, then we will do things that are by the norms in society. If we think ourselves naughty, then we will easily perform violent or deviant behavior. Furthermore, the more positive our self-concept, the more likely it is to avoid bullying behavior[7]. Whereas, if our self-concept is negative, it tends to do the bullying. In line with that, the higher the self-concept of a teenager, then they will not do juvenile delinquency, and vice versa[8]. Based on the research, the author assumes that the more selfconcept a person has, the lower the tendency to become deindividuation. According to Brooks, self-concept is a perception that is physical, social, and psychological about ourselves, which is obtained from our experiences and interactions with others [6]. Self-concept is a picture that someone has about him[9]. While, self-concept is a picture of a mixture of what someone thinks, other people's opinions about him, and what someone wants[10]. Based on this, the researchers were interested in conducting a study entitled the relationship of self-concept with deindividuation in the perpetrators of fighting between high school students in Depok, West Java. The hypothesis in this study is that there is a negative relationship between self-concept of deindividuation in the laughter of high school students in Depok.

\section{Methodology}

The method used is relational which aims to detect the extent to which variations in a factor are related to variations in one or more other factors based on the correlation coefficient [11]. Self-concept instrument is based on Fitts's (1971) theory which has several dimensions to measure self-concept, namely identity self, behavioral self, and judging self, physical self, moral/ethical self, personal self, family self, and social self[12]. The deindividuation instrument is made based on the theory of Reicher, Spears, and Postmes (1995) which has 3 dimensions for measuring deindividuation, which are screw immersion, anonymity, and Reduced Identifiability[13]. Data retrieval is done by giving the two measuring scales to the subject. Two measuring scales used in this study, the self-concept scale and deindividuation scale. This scale aims to reveal how self-concept in students involved in brawls. The dimensions contained in self-concept according to Fitts (1971) are identity self, behavioral self, and judging self, physical self, moral/ethical self, personal self, family self, and social self. 


\section{Result and Disussion}

\subsection{Results}

The normality test is the first step taken at the inferential analysis stage. The normality test used in this study is the normality test using Kolmogorov Smirnov, this normality test is calculated using computer software, with results that can be seen in the table below:

Table1. Normality test table

\begin{tabular}{llll}
\hline Name of measuring Instrument & Significance Value & A & Statement \\
\hline Self Concept & 0,191 & 0,05 & Normal Distribution \\
Deindividuation & 0,657 & 0,05 & Normal Distribution \\
\hline
\end{tabular}

Based on the table above, it is known that the data on self-concept variables and deindividual variable data are normally distributed. Therefore, after it is known that the data are normally distributed, then testing the hypothesis using the Pearson product moment correlation or Pearson test.

Table 2. Pearson correlation test table

\begin{tabular}{lllll}
\hline Variable & $\begin{array}{l}\text { Pearson } \\
\text { Correlation }\end{array}$ & Pvalue & A & N \\
\hline $\begin{array}{l}\text { Relationship between self-concept and deindividuation in } \\
\text { brawls between high school students in Depok. }\end{array}$ & $-0,369$ & 0,000 & 0,05 & 80 \\
\hline
\end{tabular}

Based on the table above, it is obtained a value of $\mathrm{P}$-value $<\alpha$, with a value of $\mathrm{P}$-value $0.00<\alpha 0.05$, thus based on the test criteria, then $\mathrm{H} 1$ is accepted or $\mathrm{H} 0$ is rejected. Then it can be concluded that there is a negative relationship between self-concept and deindividuation in the brawl between high school students in Depok.

\subsection{Discussion}

The existence of a negative relationship between self-concept deindividuation shows that a negative self-concept will lead to negative behaviors as well. Students with a negative selfconcept will easily fall into negative acts, in this case, the brawl. Students who participated in the action brawl, has a self-concept that is quite negative, it is reflected in the behavior at school, such as lack of discipline against the school rules, like ditching, looks untidy, less run religious orders, and yet stints as a student with well.This is similar to the opinion Rachmat (2012) our tendency to behave by the concept of self-referred to as behavior that might occur[6]. So, the authors argue, if we consider ourselves to be stupid, then we would be lazy to learn. If we find ourselves well, then we will do things as per the norm in society. If we believe ourselves to be naughty, then we will easily do things that are violent or deviant behavior. Furthermore, more positive concept of ourselves, they tended to avoid bullying behavior. Whereas, if the concept of ourselves is negative, then it tends to do the bullying. Correspondingly, according to Kholidah (2016) the higher the self-concept of a teenager, then they will not commit delinquency, and vice versa[8]. By doing so, a negative self-concept would result in negative behavior, whereas a positive self-concept, will result in positive behavior anyway.Correspondingly, according to Roger (1951) concept of self is something that happens in one's consciousness, people will be aware of what is done to him, these 
individuals will also evaluate about what he had done[10]. Therefore, individuals maintain consistency and congruence between self and experiences, so that way people behave is things that are consistent with the concept itself.

The self-concept here plays an important role in preventing student brawls that perpetrators do not get into a state of deindividuation.Deindividuation occurs when a person commits antisocial acts undesirable because of the interest of individuals in the group. A person may experience deindividuation if it has much in common with other group members.Heconvinced that his actions would not be considered as an act of an individual, but as a class action, and was not going to be held accountable for his actions [5]. A positive selfconcept will keep students offender brawl order not to lose consciousness and also the regulation itself. Self-awareness and also the regulation should be maintained so that the students can remain to behave according to the norms in force.

This is in line, states that the experiences of the group reduces self-awareness (selfawareness) and subtractself-consciousness that impacts on behavior that is incompatible with the norms[14]. Diener, Dunn and Rogers $(1980,1980,1989)$ state that consciousness is not from themselves or from people who deindividuated less controlled, experiencing a lack of self-regulation, is more likely to act without thinking about values their values, and more responsive to the situation[14].

Furthermore,the decline in self-directed individual consciousness to arrive at a state of deindividuation, because they impede on their self-awareness as individuals and of monitoring their behavior[15]. As a result, the loss of identity it allows a person to act aggressively or deviate from acceptable social behavior, when they are in a group than when they are alone.Deindividual circumstances self-awareness will be reduced so that it cannot prevent deviant behavior and negate one's self-regulation, this causes a person unable to maximize cognitive function to guide behavior in a better direction[16]. At other times, the inability to carry out self-regulation makes individuals more vulnerable to being influenced by the environment. The condition of anonymity experienced by the students so easily lead into a brawl could have been avoided if the discount positive self-concept. Anonymous is a state where one's identity cannot be recognized or identified[13]. According to Silke (2003) found that of 500 violent attacks, there were 206 violent attacks were carried out with disguises, such as masks, headgear, or other facial disguises. This disguise is done to cover their identity to avoid being recognized by others. Abusers undercover would tend to cause more severe injuries, attack people more, and do more acts of vandalism or destruction [17]. Diener (1980) in others research stressed the anonymous condition causes a person can lose their social consciousness as an individual. Loss of consciousness is the main factor that causes a person to experience situationdeindividuation, The importance of positive self-concept would keep the individual loses consciousness even in conditions of anonymity[18]. As explained previously, there are a negative correlation between self-concept deindividuation the perpetrator's brawl interscholastic high school students. The study also found that $16.25 \%$ of the subjects are in deindividuation score is low, it means that the subject is still able to control the behavior of himself and can assess the appropriate behavioris done when in a group so that it can avoid the occurrence of such brawl.These findings indicate a happy thing because there is still hope for students to be better.The researcher concluded that there were at least several reasons that made the subject not to engage in brawl behavior, both internal and external. Internal reasons, including thinking in the direction of a better future and wanting to boast of parents. External reasons include police who have taken preventive efforts, fear of going to jail and family factors. Those are some reasons behind the students who are brawling so that 
they can better control their self-awareness and self-regulation, this results in reduced brawl events among students.

\section{Conclusion}

Based on the retrieval of data and the results of calculations obtained, it can be concluded that: 1) $26.25 \%$ of students have a negative self-concept, $55 \%$ of students have a moderate self-concept, and $18.75 \%$ of students have a positive self-concept. A total of 13 samples or $16.25 \%$ were in the category of low deindividuation scores, as many as 53 samples or $66.25 \%$ were in the category of moderate deindividuation scores, and as many as 14 samples or $17.50 \%$ were in the category of high deindividuation scores. 2) There is a negative relationship between self-concept and deindividuation in inter-student high school brawls in Depok. This finding means that the lower the self-concept value of the students, the higher the deindividuation value. Likewise, vice versa, the higher the value of self-concept, the lower the value of deviation. 3) Pearson coefficient value obtained is $-0,369$.

\section{References}

[1] K. Kartono, Patologi Sosial II: Kenakalan Remaja. Raja Grafindo, (2011)

[2] T. P. KBBI, Kamus Besar Bahasa Indonesia. (2008)

[3] A. N. Jamaludin, Dasar-Dasar Patologi Sosial. Pustaka Setia, (2016)

[4] L. Festinger, A. Pepitone, and T. Newcomb, "Some consequences of de-individuation in a group," J. Abnorm. Soc. Psychol., vol. 47, no. 2 SUPPL., pp. 382-389 (1952)

[5] J. E. Singer, C. A. Brush, and S. C. Lublin, "Some aspects of deindividuation: Identification and conformity,” J. Exp. Soc. Psychol., vol. 1, no. 4, pp. 356-378 (1965)

[6] J. Rahmat, Psikologi Komunikasi, (2005)

[7] F. Saifullah, "Hubungan Antara Konsep Diri Dengan Bullying Pada Siswa-Siswi Smp," eJournal Psikologi., vol. 4, no. 2, pp. 200-213 (2016)

[8] D. I. Kholidah, "Hubungan Konsep diri Dengan Kenakalan Remaja Penelitian Pada Siswa Kelas VII Di Sekolah Menengah Petama Negeri 1 Pakis," (2016)

[9] E. B. Hurlock, "Psikologi Perkembangan:," in Erlangga, p. 447 (2002)

[10] R. B. Burns and C. B. Dobson, "The self-concept," in Introductory Psychology, 1984, pp. 473505 (1993)

[11] S. Suryabrata, Metodologi Penelitian. Raja Grafindo (1998)

[12] W. H. Fitts, "The self-concept and self-actualization.," Stud. Self Concept, vol. Mo 3, p. 108 (1971)

[13] S. D. Reicher, R. Spears, and T. Postmes, "A Social Identity Model of Deindividuation Phenomena," Eur. Rev. Soc. Psychol., vol. 6, no. 1, pp. 161-198 (1995)

[14] D. G. Myers, "Social psychology.," in Social Psychology, pp. 1-29 (2012)

[15] E. Diener, "Deindividuation, self-awareness, and disinhibition," J. Pers. Soc. Psychol., vol. 37, no. 7, pp. 1160-1171 (1979)

[16] B. Li, The Theories of Deindividuation. (2010)

[17] A. Silke, "Deindividuation, anonymity, and violence: Findings from northern ireland," J. Soc. Psychol., vol. 143, no. 4, pp. 493-499 (2003)

[18] SE. Diener, "Deindividuation: The absence of self-awareness and self-regulation in group members," in The psychology of group influence, pp. 209-242 (1980) 